\title{
Impaired oxidative balance and association of blood glucose, insulin and HOMA-IR index in migraine
}

\author{
Necat Yilmaz', Ozgur Aydin', Aysenur Yegin ${ }^{1 *}$, Aysun Tiltak², Esin Eren ${ }^{3}$, Guzin Aykal $^{1}$ \\ ${ }^{1}$ Central laboratories of Antalya Education and Research Hospital of Ministry of Health, Antalya, Turkey \\ ${ }^{2}$ Neurology clinic of Antalya Education and Research Hospital of Ministry of Health, Antalya, Turkey \\ ${ }^{3}$ Antalya Public Health Center of Ministry of Health, Antalya, Turkey \\ *Corresponding author: aysenuryegin@yahoo.com
}

\begin{abstract}
Introduction: The nature of the relationship between glucose metabolism and occurrence of migraine has not been elucidated precisely. This study investigated the status of oxidative/antioxidative balance and its relationship with the glucose metabolism in migraineurs to get new points of view for the underlying oxidative mechanisms.
\end{abstract}

Materials and methods: Sixty migraineurs and 46 control subjects were included in the study. Oxidative stress index, total oxidant and antioxidant status of both groups were examined in addition to the insulin and HOMA-IR index levels.

Results: HOMA-IR index was significantly enhanced in migraineurs $(P=0.038)$; similarly oxidative stress index and total oxidant status were higher in patients compared to the controls $(\mathrm{P}<0.001$ for both).

Conclusion: This preliminary study shows that oxidative/antioxidative balance shifts towards the oxidative status in migraine. Higher total oxidant status and elevated HOMA-IR index might play a role in the potential early pathogenesis for migraine.

Key words: migraine; oxidant; antioxidant; HOMA index; oxidative stress.

\section{Introduction}

Migraine is a chronic disorder with complex pathophysiology involving both the metabolism and neuro-vascular mechanism (1). Associations between migraine and vascular disorders such as coronary heart disease and stroke have been reported in previous studies. In addition, an association has been documented between migraine and vascular diseases such as hypertension and subclinical ischemic brain lesions (2).

In recent years, the idea that glucose metabolism throughout the body is coordinated by the brain has gained growing support. Nowadays, there is growing evidence that alterations in the insulin and glucose metabolism may be involved in the pathogenesis of migraine (3). Rainero et al. observed that insulin resistance is more common in pa- tients with migraine (4). Moreover, migraine is a disease with a variety of comorbid disorders, including diabetes mellitus (5). It has long been understood that blood sugar can have an impact on migraine disease; indeed the most frequent triggering factor reported by migraineurs is fasting. Studies suggest that migraine is more likely in susceptible subjects when there is low insulin receptor activation (6-8). Insulin is also thought to influence brain metabolism and cerebral blood flow through insulin receptors, which are found in many parts of the brain (9). Interestingly, it is well known that insulin resistance (IR) is considered to be a risk factor for neurovascular diseases such as hypertension and stroke (10). 
In 1976, Robert Turner and Rury Holman developed the concept that fasting plasma insulin and glucose levels were determined, in part, by a hepatic-beta cell feedback loop (11). Many years later, in 1985, David Matthews published an expanded and more comprehensive structural model known as the Homeostasis Assessment Model (HOMA) (12). In 1998, Jonathan Levy published an updated HOMA model (HOMA2) which took account of variations in hepatic and peripheral glucose resistance (13). On the other hand, the role of free radicals and oxidative stress in neurological disorders has only recently been recognized (14). Oxidative stress is the result of an excessive formation of chemically unstable by-products, called free radicals, within the cell (15). Under normal conditions, the cell is able to destroy the free radicals; however, when excessive free radicals accumulate, these molecules mount an attack against the cell in search of chemical stability (16). It is considered that brain and neural tissue are more susceptible to oxidative damage than other tissues or organs (17). Enhanced oxidative stress is observed in a number of acute and chronic diseases of the central nervous system. Oxidative stress is also believed to play a role in the pathogenesis of migraine (18).

The main aim of this study was to verify whether migraineurs have abnormalities of the glucose and insulin metabolism, at baseline. A secondary aim was to search for a correlation between serum glucose and/or insulin levels and oxidative balance in patients with migraine.

\section{Materials and methods}

\section{Subjects}

Sixty patients (48 female, 12 male; age 34 (25-43) years) who had presented at the Neurology Outpatient Clinic of Education and Research Hospital were prospectively included in the study. The patients were evaluated and diagnosed by the same neurologist on the basis of The International Classification of Headache Disorders, 2nd edition (19). Forty-six age- and sex-matched healthy controls (37 female, 9 male; age 35 (26-44) years) were enrolled for comparison. The control group consisted of volunteers from the hospital staff who had never had recurrent primary headaches. All the parti- cipants belonged to the same ethnic group and had comparable socioeconomic status. The patients with migraine, or subjects in the control group with an unstable medical condition (e.g. cardiovascular, hepatic, renal or endocrine disorder) within the past 2 years; or the ones using any medications - e.g. lipid lowering agents or antioxidant drugs - that could influence the results, were excluded. Patients were headache-free for at least 24 hours. All subjects had full physical examination and were asked to complete a general questionnaire and gave informed consent before the onset of study. The self-limited questionnaires were the gold standard for measuring disease activity and functional capacity in patients. The following data were recorded for each patient: age, sex, age at onset of disease, number of days with headache per month (less than 3 days, more than 3-less than 12 days, more than 12 days), severity of headache (mild, moderate, severe), chronic treatments, alcohol consumption, smoking, family history of cardiovascular disease. Blood pressure was measured manually with a sphygmomanometer. Hypertension was defined as systolic blood pressure of at least $140 \mathrm{~mm} \mathrm{Hg}$, diastolic blood pressure of at least $90 \mathrm{~mm} \mathrm{Hg}$, otherwise physician diagnosed hypertension. Body mass index was calculated as weight in kilograms divided by height in meters squared.

This study was performed in accordance with the ethical standards set by the Declaration of Helsinki and was approved by the local ethics committee.

\section{Samples}

Blood samples were obtained after an overnight fast. Serum samples were then separated from the cells by centrifugation for 10 minutes at a centrifugation force of $3000 \times \mathrm{g}$. Glucose and insulin were measured immediately after sampling. Remaining serum portions were stored at $-80^{\circ} \mathrm{C}$ and used to analyze Total Oxidant Status (TOS) and Total Antioxidant Status (TAS).

\section{Measurement of the serum glucose, insulin and HOMA -IR index}

The levels of fasting glucose were determined by using commercially available assay kits (Abbott Diagnostics, Abbott Park, Illinois, USA) with an au- 
toanalyzer (Architect ${ }^{\oplus} \mathrm{C} 16000$, Abbott Diagnostics, Abbott Park, Illinois, USA). Serum insulin levels were measured using an automated chemiluminescence autoanalyzer (UniCel ${ }^{\circledR}$ Dxl 800 Immunoassay System, Beckman Coulter, Krefeld, Germany). The insulin resistance index was calculated on the basis of fasting values for glycaemia and insulinemia, according to the homeostasis model assessment $($ HOMA): insulin resistance $(\mathrm{HOMA}-\mathrm{IR})=$ fasting insulinaemia $(\mathrm{mU} / \mathrm{mL}) \times$ fasting glycaemia $(\mathrm{mmol} /$ L)/22.5 (12).

\section{Measurements of the total oxidant and antioxidant statuses of serum}

The TAS and TOS of the serum were measured by commercially available kits (Rel Assay ${ }^{\circledR}$ DiagnostiCs, Gaziantep, Turkey) with an autoanalyzer (Architect ${ }^{\circledR} \mathrm{c} 16000$, Abbott Diagnostics, Abbott Park, Illinois, USA), using novel automated colorimetric measurement methods for both statuses developed by Erel $(20,21)$. In TAS method, which has a precision value lower than $3 \%$, antioxidants in the sample reduce dark blue-green colored 2, 2'-azino-bis (3-ethylbenzthiazoline-6-sulphonic acid) (ABTS) radical to colorless reduced ABTS form. The change of absorbance at $660 \mathrm{~nm}$ is related with total antioxidant level of the sample. Using this method, the antioxidative effect of the sample against the potent free radical reactions initiated by the produced hydroxyl radical, is measured. The results are expressed as micromolar trolox equivalent per liter $(22,23)$.

In TOS method, which also has a precision value lower than $3 \%$, oxidants present in the sample oxidize the ferrous ion-chelator complex to ferric ion. The ferric ion makes a colored complex with chromogen in an acidic medium. The color intensity, which can be measured spectrophotometrically, is related to the total amount of oxidant molecules present in the sample. The results are expressed in terms of micromolar hydrogen peroxide equivalent per liter ( $\mu \mathrm{mol} \mathrm{H}_{2} \mathrm{O}_{2}$ Equiv. /L) $(22,23)$

\section{Oxidative Stress Index}

The percentage ratio of TOS level to TAS level was accepted as oxidative stress index (OSI) (24). The OSI value was calculated according to the following formula: OSI (arbitrary unit) = TOS (micromolar hydrogen peroxide equivalent per liter)/TAS (micromolar trolox equivalent per liter (25).

\section{Statistical analysis}

Statistical analyses were carried out using the statistical software version 11.5.1.0 (MedCalc ${ }^{\oplus}$, Mariakerke, Belgium). In normally distributed groups the results were presented with mean and $\mathrm{SD}$, otherwise with medians and interquartile range. Data on age are presented as median and range. The significance of the differences between groups was determined by Student's unpaired t-test for normal distributions, and by the Mann-Whitney U-test in abnormal distributions. Pearson correlation coefficient and Spearman correlation coefficient were used to test the strength of any associations between different variables. $P$ values less than 0.05 were considered statistically significant.

\section{Results}

Demographic and clinical data of migraine patients and controls are summarized in Table 1. The female migraineurs (81\%) dominated the patient group as expected. Our control group was free of hypertension making the $P$ value significant automatically. The questionnaire gave us detailed information about the duration of disease, number of days with headache attacks in a month, severity of pain and how effective the headache was in the migraineurs' daily life (Table 1).

Compared to the control group, serum fasting glucose, insulin levels and HOMA-IR index were statistically significantly higher $(P<0.001, P=0.026, P=$ 0.038 , respectively) in the patient group. We also observed that TOS levels and OSI were significantly higher in migraineurs ( $P<0.001$ for both), as shown in Table 2. It was interesting to observe that migraineurs having a headache frequency of less than 3 days per month $(\mathrm{N}=22)$ showed a lower HOMA-IR level compared to the ones having a headache frequency of more than 3 days but less than 12 days per month $(\mathrm{N}=33)(\mathrm{P}=0.050)$. Statistical analysis showed a weak positive Pearson correlation between TAS and HOMA-IR in the control group ( $r=0.296, P=0.045)$; and a weak positive Spearman correlation between BMI and HOMA-IR $(r=0.282, P=0.030)$ in the migraine group. 
Migraine patients were divided into two subgroups, namely with-aura (MWA) and without-aura (MWOA) migraineurs. We did not observe any sig- nificant differences between the subgroups, other than a lower fasting glucose level in aura positive subgroup $(P=0.015)$ (Table 3$)$.

TABLE 1. Demographic and clinical data of migraine patients and controls

\begin{tabular}{lccc}
\hline Parameter & $\begin{array}{c}\text { Patients } \\
\mathbf{N}=\mathbf{6 0}\end{array}$ & $\begin{array}{c}\text { Controls } \\
\mathbf{N}=\mathbf{4 6}\end{array}$ & $\mathbf{P}$ \\
\hline Age & $34(25-43)$ & $35(26-44)$ & 0,470 \\
Gender (Male, N) & 11 & 10 & 0,840 \\
Hypertension (N) & 9 & 0 & 0,001 \\
Smoking (N) & 9 & 12 & 0,240 \\
History of CVD (N) & 22 & 9 & 0,080 \\
BMl (kg/m ${ }^{2}$ ) & $24.8 \pm 3.4$ & - & 0,220 \\
Duration of disease & $6.0 \pm 5.1$ & less than 3 & \\
Headaches in a month, days & less than 3 to more than 12 & mild to medium \\
Severity of headaches & medium to severe & very rare & Caucasian \\
Disability in daily life & common & & \\
Race & Caucasian & &
\end{tabular}

TABLE 2. Levels of biochemical parameters in patient and control group of subjects

\begin{tabular}{lccc}
\hline Parameter & $\begin{array}{c}\text { Patients } \\
\mathbf{N = \mathbf { 6 0 }}\end{array}$ & $\begin{array}{c}\text { Controls } \\
\mathbf{N = \mathbf { 4 6 }}\end{array}$ & $\mathbf{P}$ \\
\hline Glucose $(\mathrm{mmol} / \mathrm{L})$ & $4.51 \pm 0.52$ & $4.07 \pm 0.70$ & $<\mathbf{0 . 0 0 1}$ \\
Insulin (ulU/mL) & $6.96(5.49-8.21)$ & $5.20(3.60-7.92)$ & $\mathbf{0 . 0 2 6}$ \\
HOMA-IR (units) & $1.23(0.87-1.53)$ & $0.94(0.77-1.11)$ & $\mathbf{0 . 0 3 8}$ \\
TAS (nmol Trolox/L) & $1.35 \pm 0.15$ & $1.37 \pm 0.18$ & 0.483 \\
TOS ( $\mu$ mol $\mathrm{H}_{2} \mathrm{O}_{2}$ Equiv./L) & $6.78(4.38-10.78)$ & $3.53(2.65-5.65)$ & $<\mathbf{0 . 0 0 1}$ \\
OSI (arbitrary unit) & $500(326-819)$ & $268(194-388)$ & $<\mathbf{0 . 0 0 1}$ \\
\hline
\end{tabular}

TABLE 3. Serum fasting glucose, insulin levels and HOMA-IR index, TAS, TOS and OSI levels of migraineurs with and without aura

\begin{tabular}{lccc}
\hline Parameter & $\begin{array}{c}\text { MWA } \\
\mathbf{( N = 1 1 )}\end{array}$ & $\begin{array}{c}\text { MWOA } \\
\mathbf{( N = 4 9 )}\end{array}$ & P \\
\hline Glucose $(\mathrm{mmol} / \mathrm{L})$ & $4.22(3.93-4.48)$ & $4.56(4.26-4.89)$ & 0.015 \\
Insulin $(\mathrm{IU} / \mathrm{mL})$ & $5.69(3.73-8.56)$ & $7.16(4.05-11.74)$ & 0.400 \\
HOMA-IR (units) & $1.07(0.57-1.52)$ & $1.23(0.73-2.29)$ & 0.349 \\
TAS (nmol Trolox/L) & $1.34(1.26-1.43)$ & $1.35(1.26-1.44)$ & 0.639 \\
TOS( $\mu$ molH2O2Equiv./L) & $6,78(4.45-10.51)$ & 0,473 \\
OSI(arbitrary unit) & $6,54(3.51-12.06)$ & $494(331-818)$ & 0,730 \\
\hline MWA - migraineurs with aura; MWOA - migraineurs without aura & &
\end{tabular}




\section{Discussion}

Chronic oxidative stress may lead to degeneration of neurons and the degenerative diseases. Thus, it has been shown that oxygenated free radicals are able to alter vascular function and to disturb cellular homeostasis (26). On the other hand, elevated extra and intracellular glucose concentrations result in an oxidative stress. Evidence has accumulated suggesting that diabetic patients are under oxidative stress and that complications of diabetes seem to be partially mediated by oxidative stress (27).

The migraineurs in our study had higher basal plasma insulin levels and raised basal plasma glucose values. A higher basal plasma insulin level probably causes the basal plasma glucose to rise until the reduced number of beta cells are stimulated enough to secrete a normal basal insulin level (28). The increased plasma glucose load further stresses the remaining beta cells which then have to operate closer to their maximal capacity in migraineurs (29). Accordingly, McCarty et al. recently reported that five single-nucleotide polymorphisms within the insulin receptor gene showed significant association with migraine (30). In addition, Gruber et al. investigated the insulin and glucose metabolism in migraineurs and showed that hyperinsulinaemia was associated with migraine and, furthermore, was correlated with increased nitric oxide stress (31). The magnitude of the basal plasma insulin gives a measure of the degree of insulin resistance associated with impaired oxidative balance (31). Insulin resistance may also be associated with an intracellular production of free radicals, which in turn could be responsible for a deterioration of insulin action, thus leading to a vicious circle (32). In a recent study, Bourquard et al. provided evidence that factors secreted by activated paraoxonase 2-deficient macrophages - an enzyme with undefined antioxidant properties and protects against atherosclerosis - are capable of altering insulin signaling consistent with that observed in vivo. (33). Indeed, metabolic disturbances and oxidative stress seem to be tightly related, an improved glycemic control being associated with a lowering of the prooxidant status.

We have found higher levels of plasma total oxidant status and higher OSIs in migraine patients com- pared to the control subjects. Moreover, the migraineurs having a headache frequency of less than 3 days per month in our study showed a lower HOMA-IR level compared to the ones having a headache more than 3 but less than 12 days per month. Similarly, in a recent study, Alp et al. found OSI to be significantly increased, and total-SH and TAS to be decreased in patients with migraine. They also detected significant negative correlations between total-SH levels and the duration of headaches in the patient group (34). Disorders of oxidantantioxidant balance underlie a number of acute and chronic diseases of the central nervous system including epilepsy and migraine (35). A relationship between glucose concentration and oxidative stress has been shown in cultured cells. Several mechanisms seem to be involved in the development of an oxidative stress in the presence of elevated glucose concentrations, namely glucose autoxidation, protein glycation, advanced glycation end products (AGE) formation. As glycated proteins, AGEs are also able to produce oxygenated free radicals via complex biochemical mechanisms (3638). In addition, glucose is reduced by the aldose reductase into sorbitol which is oxidized to fructose by the sorbitol dehydrogenase. NADPH is required for the activity of aldose reductase. Therefore, an enhancement of the polyol pathway results in an intracellular depletion of NADPH (39). Antioxidant enzymes such as glutathione reductase which regenerate reduced glutathione need NADPH. Thus, an intracellular depletion of this cofactor, by decreasing the activity of glutathione reductase (TAS component), decreases the intracellular content of reduced glutathione, which constitutes an important factor for the protection towards oxygenated free radical-induced damages $(40,41)$.

Possible sources of oxidative stress in migraine subjects (enhanced HOMA index) include an increased production of radical oxygen species, especially from glycation or lipoxidation processes, and decreased enzymatic or non-enzymatic antioxidant defense system (42-45).

To conclude, our study provides evidence for a possible mechanism linking impaired glucose metabolism and enhanced oxidative stress index in migraineurs.

Potential Conflicts of Interest: None declared. 


\section{References}

1. Hamed SA. The vascular risk associations with migraine: relation to migraine susceptibility and progression. Atherosclerosis 2009;205:15-22.

2. Tietjen EG. Migraine and ischaemic heart disease and stroke: potential mechanisms and treatment implications. Cephalalgia 2007; 27:981-7.

3. Cavestro C, Rosatello A, Micca G, Ravotto M, Marino MP, Asteggiano G, Beghi E. Insulin metabolism is altered in migraineurs: a new pathogenic mechanism for migraine? Headache 2007; 47:1436-42.

4. Rainero I, Limone P, Ferrero $M$, Valfrè $W$, Pelissetto C, Rubino $E$, et al. Insulin sensitivity is impaired in patients with migraine. Cephalalgia 2005;25:593-7.

5. Aamodt AH, Stovner LJ, Midthjell K, Hagen K, Zwart JA. Headache prevalence related to diabetes mellitus. The HeadHUNT study. Eur J Neurol 2007; 14:738-44.

6. Hufnagl KN, Peroutka SJ. Glucose regulation in headache: implications for dietary management. Expert Rev Neurother 2002;2:311-7.

7. Jacome DE. Hypoglycemia rebound migraine. Headache 2001;41:895-8.

8. Estevez M, Gardner KL. Update on the genetics of migraine. Hum Genet 2004;114:225-35.

9. Netzer C, Freudenberg J, Heinze A, Heinze-Kuhn K, Goebel I, McCarthy LC, et al. Replication study of the insulin receptor gene in migraine with aura. Genomics 2008;91:503-7.

10. Tietjen GE, Herial NA, White L, Utley C, Kosmyna JM, Khuder SA. Migraine and biomarkers of endothelial activation in young women. Stroke 2009;40:2977-82.

11. Turner RC, Holman RR, Matthews D, Hockaday TD, Peto J. Insulin deficiency and insulin resistance interaction in diabetes: estimation of their relative contribution by feedback analysis from basal plasma insulin and glucose concentrations. Metabolism 1979;28:1086-96.

12. Matthews DR, Hosker JP, Rudenski AS, Naylor BA, Treacher DF, Turner RC. Correct homeostasis model assessment (HOMA) evaluation uses the computer program. Diabetologia 1985;28:412-9.

13. Wallace TM, Levy JC, Matthews DR. Use and abuse of HOMA modeling. Diabetes Care 2004;27:1487-95.

14. Finsterer J. Treatment of central nervous system manifestations in mitochondrial disorders. Eur J Neurol 2011;18:28-38.

15. Ciancarelli I, Tozzi-Ciancarelli MG, Spacca G, Di Massimo C, Carolei A. Relationship between biofeedback and oxidative stress in patients with chronic migraine. Cephalalgia 2007;27:1136-41.

16. Erol I, Alehan F, Aldemir D, Ogus E. Increased vulnerability to oxidative stress in pediatric migraine patients. Pediatr Neurol 2010;43:21-4.

17. Gupta R, Pathak R, Bhatia MS, Banerjee BD. Comparison of oxidative stress among migraineurs, tension-type headache subjects, and a control group. Ann Indian Acad Neurol 2009;12:167-72.

18. Guldiken B, Guldiken S, Taskiran B, Koc G, Turgut N, Kabayel $L$, Tugrul A. Oxidative stress in migraine with and without aura. Biol Trace Elem Res 2008;126:92-7.
19. Headache Classification Subcomittee of International Headache Society. The international classification of headache disorders. 2nd edition. Cephalalgia 2004;24 suppl 1:9-160.

20. Erel O. A novel automated direct measurement method for total antioxidant capacity using a new generation more stable ABTS radical cation. Clin Biochem 2004;37:277-85.

21. Erel O. A new automated colorimetric method for measuring total oxidant status. Clin Biochem 2005;38:1103-11.

22. Kavakli HS, Erel O, Delice O, Gormez G, Isikoglu S, Tanriverdi F. Oxidative stress increases in carbon monoxide poisoning patients. Hum Exp Toxicol 2011;30:160-4.

23. Permpongpaiboon T, Nagila A, Pidetcha P, Tuangmungsakulchai K, Tantrarongroj S, Porntadavity S. Decreased paraoxonase 1 activity and increased oxidative stress in low lead-exposed workers. Hum Exp Toxicol 2011; [Epub ahead of print].

24. Harma $M$, Harma $M$, Erel $O$. Increased oxidative stress in patients with hydatidiform mole. Swiss Med Wkly 2003;133:563-6.

25. Horoz M, Bolukbas C, Bolukbas FF, Aslan M, Koylu AO, Selek $S$, Erel O. Oxidative stress in hepatitis $C$ infected end-stage renal disease subjects. BMC Infect Dis 2006;6:114.

26. Yilmaz G, Sürer $H$, Inan LE, Coskun $O$, Yücel D. Increased nitrosative and oxidative stress in platelets of migraine patients. Tohoku J Exp Med 2007;211:23-30.

27. Rösen $P, D u X, T$ schöpe $D$. Role of oxygen derived radicals for vascular dysfunction in the diabetic heart: prevention with a-tocopherol? Mol Cell Biochem 1998;188:103-11.

28. Kokavec A, Crebbin SJ. Sugar alters the level of serum insulin and plasma glucose and the serum cortisol: DHEAS ratio in female migraine sufferers. Appetite 2010;55:582-8.

29. Guldiken B, Guldiken S, Taskiran B, Koc G, Turgut N, Kabayel $L$, Tugrul A. Migraine in metabolic syndrome. Neurologist 2009; 15:55-8.

30. McCarthy LC, Hosford DA, Riley JH, Bird MI, White NJ, Hewett DR, et al. Single-nucleotide polymorphism alleles in the insulin receptor gene are associated with typical migraine. Genomics 2001;78:135-49.

31. Gruber HJ, Bernecker C, Pailer S, Fauler G, Horejsi R, Möller $R$, et al. Hyperinsulinaemia in migraineurs is associated with nitric oxide stress. Cephalalgia 2010;30:593-8.

32. Guldiken B, Guldiken S, Demir M, Turgut N, Kabayel L, Ozkan $\mathrm{H}$, et al. Insulin resistance and high sensitivity $\mathrm{C}-\mathrm{re}$ active protein in migraine. Can J Neurol Sci 2008;35:44851.

33. Bourguard $\mathrm{N}, \mathrm{Ng}$ C, Reddy s. Impaired hepatic insulin signaling in PON2 deficient mice - a novel role for the PON2/ ApoE axis on macrophage inflammatory response. Biochem J. 2011; [Epub ahead of print].

34. Alp R, Selek S, Alp SI, Taskın A, Kocyigit A. Oxidant and antioxidant balance in patients of migraine. Eur Rev Med Pharmacol Sci 2010;14:877-82.

35. Boćkowski L, Sobaniec W, Kułak W, Smigielska-Kuzia J. Serum and intraerythrocyte antioxidant enzymes and lipid peroxides in children with migraine, Pharmacol Rep 2008; 60:542-8. 
36. Giardino I, Edelstein D, Brownlee M. Bcl-2 expression antioxidants prevent hyperglycemia-induced formation of intracellular advanced glycation end products in bovine endothelial cells. J Clin Invest 1996;97:1422-8.

37. Hunt JV, Dean RT, Wolff SP. Hydroxyl radical production and autoxidative glycosylation. Glucose autoxidation as the cause of protein damage in the experimental glycation model of diabetes mellitus and ageing. Biochem J 1988;256:20512.

38. Gillery P, Monboisse JC, Maquart FX, Borel JP. Glycation of proteins as a source of superoxide. Diabetes Metab 1988; 14:25-30.

39. Lee AY, Chung SS. Contributions of polyol pathway to oxidative stress in diabetic cataract. Faseb J 1999;13:23-30.

40. Tesfamariam B. Free radicals in diabetic endothelial cell dysfunction. Free Radic Biol Med 1994;16:383-91.
41. Greene DA, Stevens MJ. The sorbitol-osmotic and sorbitol redoxhypotheses. In: Le Roith D, Taylor SI, Olefsky JM, eds. "Diabetes Mellitus". Philadelphia: Lippincott-Raven Publishers, 1996.

42. Shukla R, Barthwal MK, Srivastava N, Sharma P, Raghavan $S A, N a g D$, et al. Neutrophil-free radical generation and enzymatic antioxidants in migraine patients. Cephalalgia 2004;24:37-43.

43. Leinonen JS, Alho $H$, Harmoinen A, Lehtimaki T, Knip M. Unaltered antioxidant activity of plasma in subjects at increased risk for IDDM. Free Radic Res 1998;29:159-64.

44. Cerellio A, Bortolotti N, Crescentini A, Motz E, Lizzio S, Russo $A$, et al. Antioxidant defences are reduced during the oral glucose tolerance test in normal and non-insulin-dependent diabetic subjects. Eur J Clin Invest 1998;28:329-33.

45. Tribe RM, Poston L. Oxidative stress and lipids in diabetes: a role in endothelium vasodilator dysfunction? Vasc Med 1996;1:195-206.

\section{Poremećena oksidacijska ravnoteža i povezanost s koncentracijom glukoze i inzulina u krvi te HOMA-IR indeksom kod migrene}

\section{Sažetak}

Uvod: Priroda veze između metabolizma glukoze i pojave migrene još nije precizno razjašnjena. Ovo istraživanje ispituje status ravnoteže odnosa oksidansa i antioksidansa u organizmu te njenu vezu s metabolizmom glukoze kod bolesnika s migrenom kako bi se dobila nova saznanja 0 oksidacijskim mehanizmima u pozadini.

Materijali i metode: U ovom je istraživanju sudjelovalo šezdeset (60) ispitanika s migrenom i četrdeset i šest (46) kontrolnih ispitanika. Kod obje skupine određeni su indeks oksidacijskog stresa, ukupni oksidacijski i antioksidacijski status kao dodatak određivanju koncentracije inzulina te HOMA-IR indeksa (engl. homeostasis model assessment of insulin resistance, HOMA-IR).

Rezultati: HOMA-IR indeks bio je značajno povišen kod ispitanika s migrenom ( $P=0,039)$; isto su tako indeks oksidacijskog stresa i ukupni oksidacijski status bili viši kod ispitanika s migrenom nego kod kontrolnih ispitanika ( $P<0,001$ kod obje skupine ispitanika).

Zaključci: Ovo preliminarno istraživanje pokazuje kako se ravnoteža odnosa oksidansa i antioksidansa u organizmu_kod migrene pomiče prema oksidacijskom statusu. Moguće je da viši ukupni oksidacijski status i povišeni HOMA-IR indeks imaju ulogu u mogućoj ranoj patogenezi migrene.

Ključne riječi: migrena; oksidans; antioksidans; HOMA-IR indeks; oksidacijski stres 